\title{
Physical abrasion method using submerged spike balls to remove algal biofilm from photobioreactors
}

\author{
Azra Nawar ${ }^{1}$, Asif Hussain Khoja ${ }^{1,2^{*}} \mathbb{D}$, Naveed Akbar ${ }^{1}$, Abeera Ayaz Ansari ${ }^{1,3}$, Muneeb Qayyum ${ }^{1}$ and Ehsan Ali ${ }^{4}$
}

\begin{abstract}
Objective: A major factor in practical application of photobioreactors (PBR) is the adhesion of algal cells onto their inner walls. Optimized algal growth requires an adequate sunlight for the photosynthesis and cell growth. Limitation in light exposure adversely affects the algal biomass yield. The removal of the biofilm from PBR is a challenging and expansive task. This study was designed to develop an inexpensive technique to prevent adhesion of algal biofilm on tubular PBR to ensure high efficiency of light utilization. Rubber balls with surface projections were introduced into the reactor, to remove the adherent biofilm by physical abrasion technique.

Results: The floatation of spike balls created a turbulent flow, thereby inhibiting further biofilm formation. The parameters such as, specific growth rate and doubling time of the algae before introducing the balls were 0.451 day $^{-1}$ and 1.5 days respectively. Visible biofilm impeding light transmission was formed by $15-20$ days. The removal of the biofilm commenced immediately after the introduction of the spike balls with visibly reduced deposits in 3 days. This was also validated by enhance cell count $\left(6.95 \times 106\right.$ cells $\left.\mathrm{mL}^{-1}\right)$ in the medium. The employment of spike balls in PBR is an environmental friendly and economical method for the removal of biofilm.
\end{abstract}

Keywords: Chlorella vulgaris, Photobioreactor, Spike balls, Biofilm removal

\section{Introduction}

Microalgae can be cultivated in either freshwater or saline by two different methods i.e. open or closed systems $[1,2]$. Biofilm formation in PBRs is a complex process, in which algae and bacteria produce extracellular polymeric substance (EPS) to bind the cells to external surfaces of the bioreactors. Chlorella species are one of the most abundant producers of EPS [3]. Biofilm formation in PBRs diminishes the passage of light to algal cells which inhibits photosynthesis, hence reducing the cell growth and biomass yield.

Cleaning of the biofilm from PBRs is a challenging process, requiring a lot of effort and time. For instance, by using a cylindrical piece of foam, $10 \mathrm{~cm}$ long with $10 \%$ larger diameter than the inner diameter of PVC pipe,

\footnotetext{
${ }^{*}$ Correspondence: engr.asifglt@gmail.com

1 US-PAK Centre for Advance Studies in Energy (CAS-EN), National University of Sciences and Technology (NUST) H-12, Islamabad 44000, Pakistan

Full list of author information is available at the end of the article
}

the biofilm was removed with the help of air pump that pushed the foam along the pipe required high pressure [4]. Seaweeds extract has also been used to avoid biofilm formation while cultivating green algae [5]. Antifouling booster biocides are also in practice to remove marine sediments [6]. Other available techniques include the use of ozone, ultrasonic technology, and the use of large slugs of air to intermittently scour the internal surface of the tube. Continuous circulation of close fitting balls, highly turbulent flow and suspended sand or grit particles technique have also been employed to abrade any biomass adhering to the internal surface of the bioreactor [7]. All of these processes have a set of drawbacks such as the risk of reactor tube breakage, utilization of valuable chemicals, high energy input, as well as high operating and maintenance cost, which motivates to identify feasible options for algal biofilm removal.

Spike rubber ball method is an inexpensive and novel approach for effective PBR cleaning. The spike balls have a simple design and usage, which requires no special 
training or extra labor costs for handling purposes. Spike balls are reusable and can be used in multiple batch processes, thereby contributing towards minimum waste generation. This technique also encourage the effective mixing of algal cultures, without posing any adverse impact on their growth cycle. This mixing effect prevents algal biomass to settle on the walls of PBR pipes, which results in the potential biofilm reduction. Another added advantage of the process is the cost-effectiveness and application in different PBRs for biofilm removal due to the availability of the spike balls in various sizes and designs.

This study is focused on devising an innovative method of removing algal biofilm from PBRs. The set of spike balls with bristles were prepared and were circulated along with the algal culture in the airlift tubular PBR as a mobile scrubber to remove biofilm leading to less deposition and high biomass production.

\section{Main text}

\section{Experimental}

The algal strain used in this study is Chlorella vulgaris (ATCC 9765), which was obtained from AlgaeTech International, Malaysia. Chlorella vulgaris is a photosynthetic microorganism with size ranging from 2 to $10 \mu \mathrm{m}$ [8]. Chlorella vulgaris was grown in Bold's Basal media [9] at $25^{\circ} \mathrm{C}$ in a $100 \mathrm{~mL}$ flask which was subsequently diluted to $1000 \mathrm{~mL}$ with a $\mathrm{pH}$ of 6.5 . The culture was then transferred into a $480 \mathrm{~L}$ PBR using electric pump for aeration whereas day light was used as a light source. The $\mathrm{pH}$ was monitored and adjusted to 6.5 using $2 \mathrm{M} \mathrm{NaOH}$ or $2 \mathrm{M}$ $\mathrm{H}_{2} \mathrm{SO}_{4}$ solutions. All the chemicals used were of analytical grade from Sigma Aldrich.

The vertical PBR (480 L) were used for microalgae cultivation as presented in Fig. 1. The PBR consisted of vertical and horizontal pipes, a degasser, sampling point and a pump. Submerged spike balls used in the experiment were $6 \mathrm{in}$. in diameter with $0.7 \mathrm{~cm}$ long projections (completely filled with water having magnets inside). The spike balls used mechanical scrubbing action against the reactors to remove deposited algal biofilms. Furthermore, the action of spike balls kept the water agitated which discouraged the algal deposition.

A small portion of reactor pipe was removed from the PBR for analysis of the biofilm characteristics. The algal biofilm present on the fragments of PBR glass pipe was air dried and later analysed using Nanovea Optical Profilometer Ps-50 (Nanovea Corp. USA) with Nanovea 3D software. Chlorella vulgaris cell count was monitored using Neubauer Hemocytometer (China). The cell concentration was measured using Eq. (1). Where, $X_{c}$ is cell concentration, $\mathrm{T}_{\text {cell }}$ is total cells and $\mathrm{D}_{\mathrm{f}}$ is dilution factor.

$$
\mathrm{X}_{\mathrm{c}}\left(\mathrm{mL}^{-1}\right)=\left[\mathrm{T}_{\text {cell }}(5 \text { squares }) \times 5000 \times \mathrm{D}_{\mathrm{f}}\right]
$$

The dry biomass $\left(\mathrm{g} \mathrm{L}^{-1}\right)$ was used to determine the growth rate of algal culture. The specific growth rate $(r)$ per day was calculated using the Eq. (2) [10]. Where $\mathrm{N}_{t}$ and $\mathrm{N}_{0}$ are the dry biomass weights $\left(\mathrm{g} \mathrm{L}^{-1}\right)$ at time $\mathrm{T}_{\mathrm{t}}$ and $T_{0}$, respectively, and $\Delta t$ is the time interval from $T_{t}$ to $T_{0}$.

$$
\mathrm{r}=\left[\frac{\operatorname{Ln}\left(\mathrm{N}_{\mathrm{t}}\right)-\ln \left(\mathrm{N}_{0}\right)}{\Delta \mathrm{t}}\right]
$$

Algal yield was determined from the growth rate and doubling time. Cell doubling time $\left(t_{d}\right)$ was estimated using Eq. (3).

$$
\mathrm{t}_{\mathrm{d}}=\left[\frac{\ln 2}{\mathrm{r}_{\max }}\right]
$$

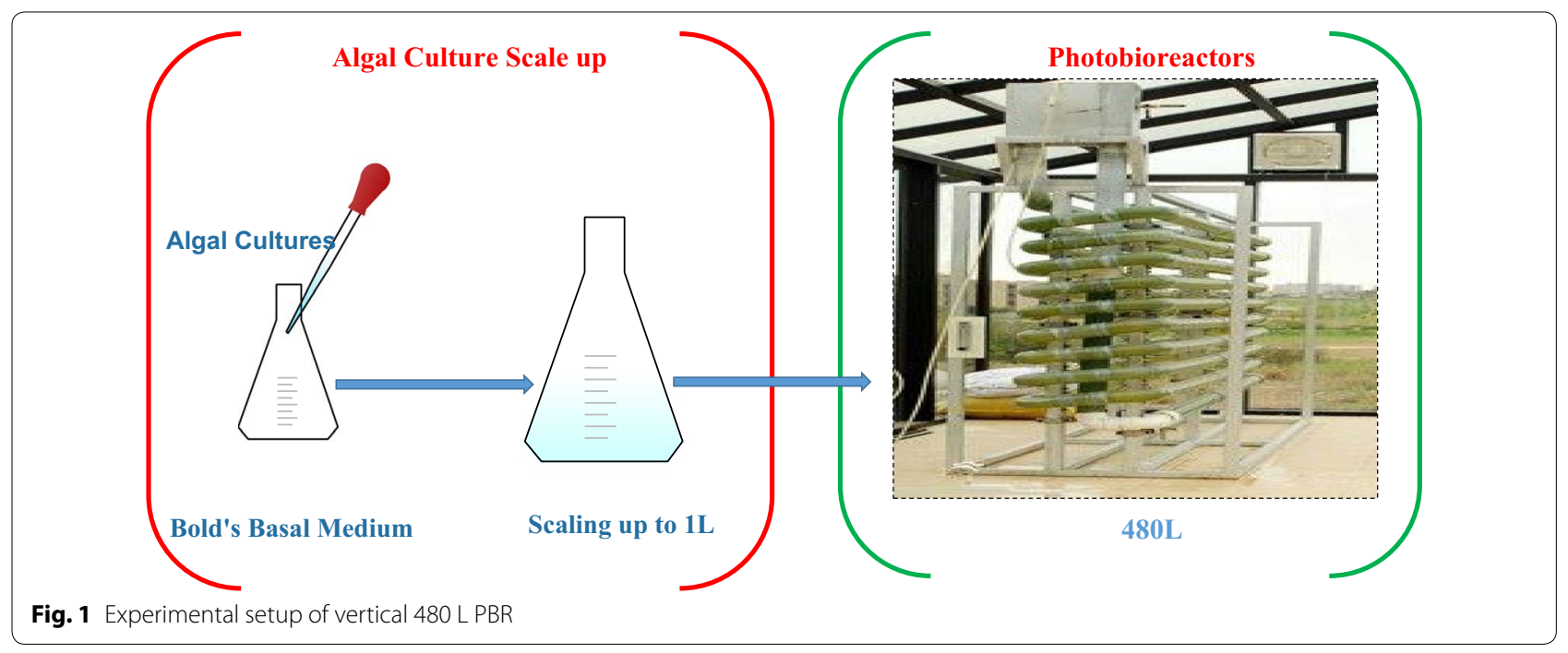




\section{Results}

The algal cultivation in PBR were conducted to investigate the impact of the spike balls on the removal of produced algal biofilm. From inoculation till day 24, the cell count was observed to increase from $1.05 \times 10^{6}$ cells $\mathrm{mL}^{-1}$ to $2 \times 10^{6}$ cells $\mathrm{mL}^{-1}$. This number doubled in 1 day, reaching $4 \times 10^{6}$ cells $\mathrm{mL}^{-1}$ on day 25 , and finally peaking at $4.85 \times 10^{6}$ cells $\mathrm{mL}^{-1}$ on day 30 as shown in Fig. 2a. On day 17, visible algal biofilm was seen appearing in the inner walls of PBR which kept accumulating till day 37 under the controlled growth environment. In the second PBR run, spike balls were introduced in the PBR on day 30 , which resulted in an abrupt increase in cell count to $6.85 \times 10^{6}$ cells $\mathrm{mL}^{-1}$. The continuation of this rise in cell count was seen until day 37 . This enhancement in cell count was not only due to the result of algal growth but also dislodging of cells previously adherent to the PBR walls as more light was able to penetrate inside the PBR pipes.

Figure 2a shows the dry biomass of algae. The maximum specific growth rate $\left(\mathrm{r}_{\max }\right)$ per day was determined from all the different values of specific growth rate $(r)$, while the maximum biomass obtained was designated as $\mathrm{N}_{\max }\left(\mathrm{g} \mathrm{L}^{-1}\right)$. The maximum specific growth rate $\left(\mathrm{r}_{\max }\right)$ was obtained to be 0.451 day $^{-1}$ while the doubling time was found to be 1.5 days. As the spike balls were introduced into the PBR on day 30, a sudden increase in the cell count was observed as shown in Fig. $2 \mathrm{a}$. The result obtained from Nanovea 3D software shows the thickness of algal biofilm is $3064 \mathrm{~nm}(3.064 \mu \mathrm{m})$ as depicted in Fig. 2b.

The spike balls were introduced into the PBR on day 30 and their effect on biofilm removal was observed by doing the visual inspection a thick layer of algal biofilm can be seen in the Fig. 3a. Nevertheless, a visible reduction in the biofilm layer was seen in 3 days after introducing the spike balls demonstrated in Fig. 3b. The image clearly show the effect of the spike balls employment into the PBR. There was a substantial effect on the amount of adherent biofilm by the brushing action of these spikes. Continues motion of these balls within the tubing ensured adequate area was covered including bottom and bends. They were easily removed via the degasser chamber and any material trapped in the projections could be cleaned with simple soap and water.

\section{Discussion}

This study attempted the removal of biofilm on the inner walls of the PBR via physical abrasion method. Optimal growth parameters for $C$. vulgaris has already been identified and it was grown for biomass production purposes. During algal growth in PBR, the major problem faced was biofilm formation. After experimentation it was found that the algal biofilm thickness was to be $3.064 \mu \mathrm{m}$ which is in good compromise with previously reported results $[11,12]$. The spike balls removed algal

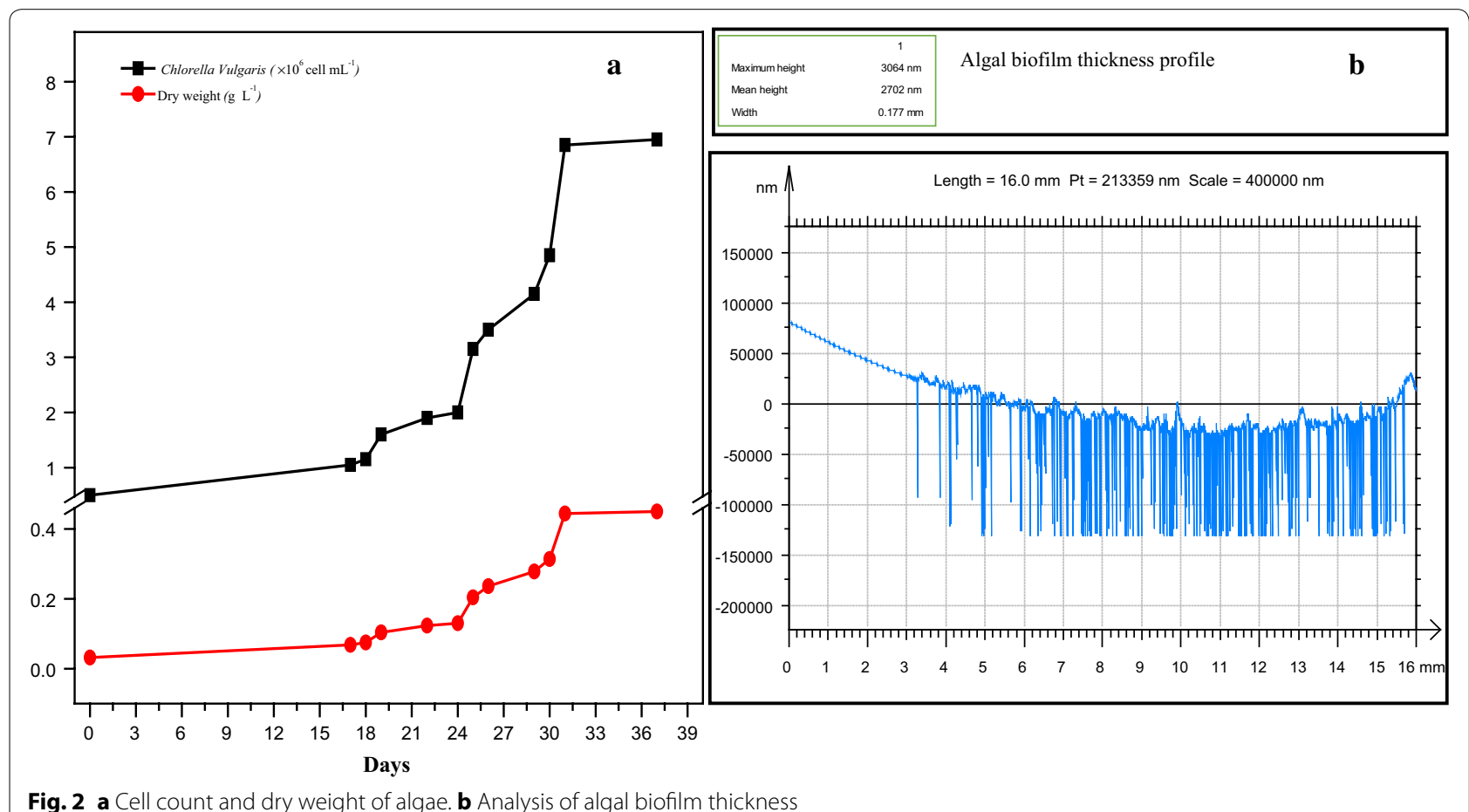

Fig. 2 a Cell count and dry weight of algae. b Analysis of algal biofilm thickness 


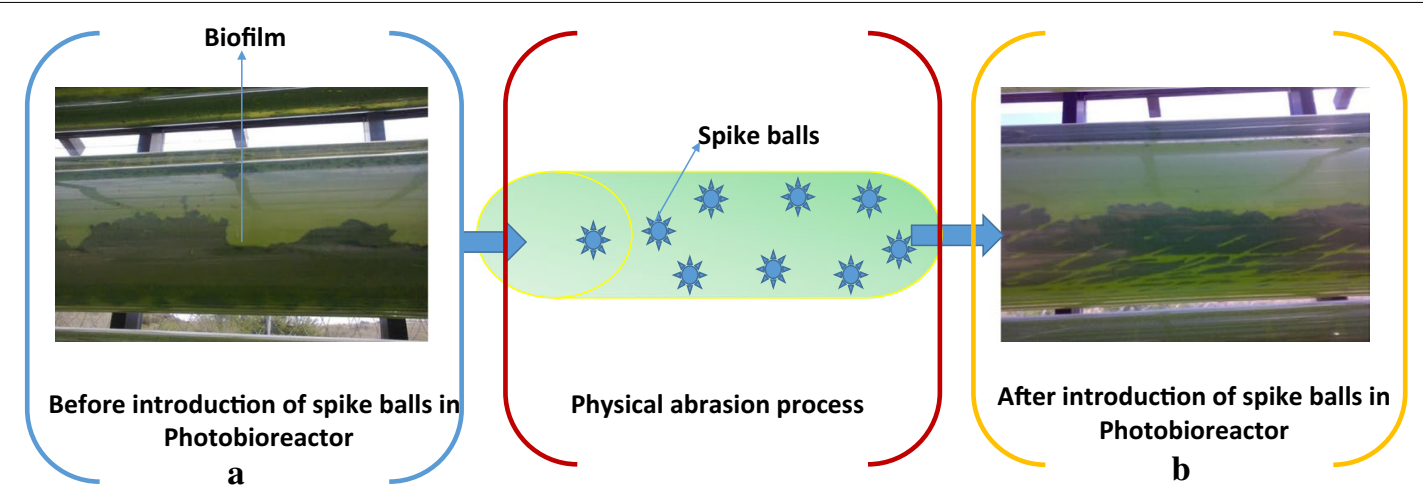

Fig. 3 Effect of Spike balls on biofilm removal. a Before removal of biofilm. b After removal of biofilm

biofilms significantly from the bioreactor and carried them into circulation. This increased the algal mass per liter of solution, and inhibit cells to stick in PBR, resulting biofilm formed is also nominal. The spikes on balls provide increase in surface area when in contact with walls of PBR. The scrubbing action of spikes also increases its mechanical efficiency.

While comparing with previously available technologies, few methods required high pressure to clean PBR which leads to breakage of reactor [13]. The using of ozone and ultrasound is expensive technology as it requires high energy input and it also destroys the algal cell $[14,15]$. The chemical methods are also harmful for algal cell growth and expansive [16]. Whereas, the provided method is not harmful to the algal cells reactor and maintenance of the reactor. The spike ball design and preparation is very simple and no extra cost is required. The method does not required any surplus energy or chemicals, so it can be considered as environmental friendly and low cost mechanical approach to remove the biofilm form PBRs.

\section{Limitations}

- Spike balls can get trapped in bends of PBR.

- A single spike ball design can limited to the particular reactor.

- Retrieval of damaged spike balls may be difficult.

\section{Abbreviations}

PBR: Photobioreactor; EPS: Extracellular polymeric substance; PVC: Polyvinyl chloride.

\section{Authors' contributions}

AN, AHK, NA, MQ and EA were involved in study conception. AN was involved in data collection and screening of experiments. $A A A, A N$ and $M Q$ were involved in data analyses. AN and AHK drafted the manuscript. All authors read and approved the final manuscript.

\section{Author details}

1 US-PAK Centre for Advance Studies in Energy (CAS-EN), National University of Sciences and Technology (NUST) H-12, Islamabad 44000, Pakistan.
${ }^{2}$ Chemical Reaction Engineering Group (CREG), Faculty of Chemical \& Energy Engineering, Universiti Teknologi Malaysia (UTM), Skudai, 81310 Johor Bahru, Malaysia. ${ }^{3}$ Department of Civil and Environmental Engineering, College of Engineering, University of Massachusetts (UMass), Amherst, MA 01002, USA. ${ }^{4}$ Punjab Bio Energy Institute, University of Agriculture, Faisalabad 38000, Pakistan.

\section{Acknowledgements}

The PBR facility used was installed at National University of Sciences and Technology by NRG Biofuel Inc. Canada. Authors also acknowledge the contributions of Mr. Naveed Ahmad (Lab Engineer) and Mr. Qamar Ud Din (Technical staff) for help and maintenance of PBR.

\section{Competing interests}

The authors declare that they have no competing interests.

\section{Availability of data and materials}

All data supporting these findings is contained within the manuscript.

\section{Consent for publication}

All authors have agreed to publish the manuscript in BMC Research Notes.

\section{Ethics approval and consent to participate}

Not applicable.

\section{Funding}

This research did not receive any specific grant from funding agencies in the public, commercial, or not-for-profit sectors.

\section{Publisher's Note}

Springer Nature remains neutral with regard to jurisdictional claims in published maps and institutional affiliations.

Received: 18 July 2017 Accepted: 25 November 2017

Published online: 02 December 2017

\section{References}

1. Abomohra AEF, et al. Microalgal biomass production as a sustainable feedstock for biodiesel: current status and perspectives. Renew Sustain Energy Rev. 2016;64:596-606.

2. Narala RR, et al. Comparison of microalgae cultivation in photobioreactor, open raceway pond, and a two-stage hybrid system. Front Energy Res. 2016;4(August):29.

3. Shen $Y$, et al. Biofilm formation in attached microalgal reactors. Bioprocess Biosyst Eng. 2016;39(8):1281-8.

4. Silva $A G$, et al. Life cycle assessment of biomass production in microalgae compact photobioreactors. GCB Bioenergy. 2015;7(2):184-94. 
5. Hannon M, et al. Biofuels from algae: challenges and potential. Biofuels. 2010;1(5):763-84.

6. Albanis TA, et al. Antifouling paint booster biocide contamination in Greek marine sediments. Chemosphere. 2002;48(5):475-85.

7. Brennan L, Owende P. Biofuels from microalgae-a review of technologies for production, processing, and extractions of biofuels and coproducts. Renew Sustain Energy Rev. 2010;14(2):557-77.

8. Vander Wiel JB, et al. Characterization of Chlorella vulgaris and Chlorella protothecoides using multi-pixel photon counters in a 3D focusing optofluidic system. RSC Adv. 2017;7(8):4402-8.

9. Ansari AA, et al. Wastewater treatment by local microalgae strains for $\mathrm{CO}_{2}$ sequestration and biofuel production. Appl Water Sci. 2017;7(7):4151-8.

10. Griffiths MJ, Harrison STL. Lipid productivity as a key characteristic for choosing algal species for biodiesel production. J Appl Phycol. 2009;21(5):493-507.

11. Almstrand $\mathrm{R}$, et al. Three-dimensional stratification of bacterial biofilm populations in a moving bed biofilm reactor for nitritation-anammox. Int J Mol Sci. 2014;15(2):2191.
12. Schnurr PJ, Espie GS, Allen DG. The effect of light direction and suspended cell concentrations on algal biofilm growth rates. Appl Microbiol Biotechnol. 2014;98(20):8553-62.

13. Biofilm removal technique using sands as a research tool for accessing microbial attachment on surface. Songklanakarin J Sci Technol. 2004;26(1):109-15.

14. Clarke RM., et al. An investigation into the efficacy of ozone for inactivation of microalgae cells in photobioreactors. In: American Society of Agricultural and Biological Engineers, Kansas City, Missouri, July 21-24, vol 1;2013. p. 1-4.

15. Mason TJ, et al. Potential uses of ultrasound in the biological decontamination of water. Ultrason Sonochem. 2003;10(6):319-23.

16. Teng CK, Hawlader MNA, Malek A. An experiment with different pretreatment methods. Desalination. 2003;156(1-3):51-8.

\section{Submit your next manuscript to BioMed Central and we will help you at every step:}

- We accept pre-submission inquiries

- Our selector tool helps you to find the most relevant journal

- We provide round the clock customer support

- Convenient online submission

- Thorough peer review

- Inclusion in PubMed and all major indexing services

- Maximum visibility for your research

Submit your manuscript at www.biomedcentral.com/submit 